http://dx.doi.org/10.18675/1981-8106.vol23.n44.p24-45

\title{
História ensinada: práticas de letramento e produção de sentido
}

Patricia Bastos de Azevedo

Departamento de Educação e Sociedade da Universidade Federal do Rio de Janeiro, Rio de Janeiro, RJ - Brasil.

patriciabazev@gmail.com

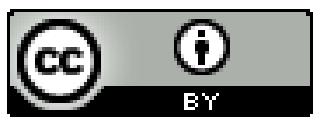

Educação: teoria e prática, Rio Claro, SP, Brasil - elSSN: 1981-8106

Está licenciada sob Licença Creative Common

\section{Resumo}

O presente artigo buscou investigar a produção de sentido em práticas de letramento na história ensinada, operando conceitualmente com o campo da linguagem a partir de Bakhtin como arcabouço teórico em interface com o currículo. O currículo, nesse sentido, é compreendido como um signo ideológico que se constitui em seu tempo-espaço sóciohistórico, em uma composição híbrida, ambivalente, complexa e polissêmica. Como foco e recorte metodológico, investigou-se, em um tempo determinado do ano de 2009, o 60 ano de escolaridade do ensino fundamental no espaço específico da sala de aula de história de uma escola estadual no Rio de Janeiro/Baixada Fluminense. Na perspectiva teórica adotada, os enunciados se constituem no processo relacional situado, com um pano de fundo sóciocultural, e o cenário composicional se relaciona diretamente com o emprego das enunciações e de suas relações intersubjetivas. Esse viés teórico possibilitou o adensamento analítico dos eventos de letramento que se materializavam no espaço da sala de aula, onde atos de ler o livro, copiar do quadro, escrever no caderno e responder provas são práticas contextualizadas da/na vida escolar.

Palavras-chave: História Ensinada. Letramento. Produção de Sentido. Currículo.

\section{History taught: literacy practices and production of meaning}

\begin{abstract}
The present study investigates the production of meaning in literacy practices in History education and it is shaped conceptually by the field of language drawn from the Bakhtin as its theoretical framework in interface with the curriculum itself. Therefore, many questions and possibilities stem from this conversation between the fields of language and the curriculum since knowledge is defined as a socially constituted production, structured by ideological signs in its social historicity and the classroom is conceived as a complex, multiple, hybrid and ambivalent space. This study focused on the 6th grade History lessons in classroom environment in an elementary state school in Rio de Janeiro / Baixada Fluminense in 2009 during a determined time. According to the theoretical perspective adopted, the statements are formed in the situated relational process as a social-cultural
\end{abstract}


backcloth whereas the compositional scenario is directly related to the usage of utterances and their inter-subjective interactions. This theoretical approach allowed the coherent analysis of the literacy events materialized within the classroom space where the act of reading a book, copying from the board, writing on the notebook and answering a test are contextualized practices of/in a day-to-day school life.

Keywords: History Taught. Literacy. Production of Meaning. Curriculum.

\section{Considerações iniciais}

O desafio fundamental deste artigo é conjugar dois campos discursivos - currículo e linguagem - buscando compreender nosso foco de investigação - história ensinada e sua interface com o letramento. Para essa tarefa, temos como principal lente teórica a filosofia da linguagem dialogando com Bakhtin. O currículo, no viés teórico que apresentamos, é pensado como um signo ideológico ${ }^{1}$ que se constitui em seu tempo-espaço, em uma composição híbrida, complexa e polissêmica, que transita por múltiplos campos discursivos e espaços enunciativos.

A aula é compreendida como um espaço social múltiplo, onde diferentes campos discursivos estão em disputa e constituem significação. Nosso olhar sobre os indícios produzidos neste artigo busca perceber o tempo-espaço de produção ideológica², o qual constitui as práticas de letramento estruturadas e corporificadas na história ensinada.

A sala de aula, no encaminhamento analítico que desenvolvemos, é entendida como um espaço repleto de múltiplos campos discursivos. São campos que se constituem ideologicamente e, dessa forma, uma produção de criação ideológica é concebida sempre como um signo.

Nossa análise sobre a produção de sentido em práticas de letramento na história ensinada operou com a concepção de produção ideológica constituída em um tempo-espaço

\footnotetext{
1 Já que nosso texto usa como principal arcabouço teórico o diálogo com o Círculo de Bakhtin, a palavra ideologia assume um sentido próprio, o qual, neste artigo, pode ser compreendido na explicação apresentada por Faraco (2009, p. 46, grifo do autor): “Como ideologia é uma palavra 'maldita' (pelas incontestáveis significações sociais que pode veicular), é importante - para evitar costumeiros mal-entendidos [...] [A] palavra ideologia é usada, em geral, para designar o universo dos produtos do 'espírito' humano, aquilo que algumas vezes é chamado por outros autores de cultura imaterial ou produção espiritual (talvez como herança de um pensamento idealista); e, igualmente, de forma da consciência social (num vocabulário de sabor materialista).

${ }^{2}$ Faraco (2009), refletindo sobre as concepções do Círculo de Bakhtin, escreve: “... todos os produtos da criação ideológica são objetos dotados de materialidade, isto é, são parte concreta e totalmente objetiva da realidade prática dos seres humanos (não se podendo estudá-los, portanto, desconectados desta realidade)" (p. 48).
} 
sócio-histórico situado: em seu sentido micro, escola e sala de aula, e em seu sentido macro, Estado, políticas públicas, currículo etc. Nesse sentido, compreendemos as práticas de oralidade, leitura e escrita na história ensinada como parte integrante da produção de sentido tecida sobre o passado e ensinada aos alunos em sala de aula na dinâmica complexa que constitui o fazer do professor.

\section{Produção de sentido}

Neste artigo, o professor de história é concebido como o protagonista da história ensinada e, assim, pensamos o aluno como protagonista da história aprendida. Não é nossa pretensão reduzir o processo ensino/aprendizagem nem dicotomizá-lo, visto que o compreendemos como uma ação circular que forma e é formada nos diversos espaços de educação; estamos, em nossa afirmação, recortando e delimitando nosso centro de interesse e salientado o foco de nosso olhar. A história ensinada possui uma assinatura do sujeito que pensa este fazer em relação ao auditório social e às múltiplas forças presentes na produção de sentido em que o ato está imerso. Nesse sentido, o professor constitui o ensinado de sua assinatura e responde socialmente por isso (BAKHTIN, 1993).

A ação do professor não está solta. Ela se situa em um emaranhado social complexo e multifacetado, constituindo o ensinado em uma perspectiva densa, complexa e produtora de sentido, em um jogo estratégico que exige plasticidade e adaptação de suas práticas no ato do ofício.

A produção de sentido na história ensinada, na abordagem que adotamos, se constitui como um processo denso e situado que demanda saberes plurais, híbridos e heterogêneos. Como situado, o ensinado é permeado pelas relações de poder do tempo-espaço escolar e do todo social que o impacta e o estrutura. São relações materializadas em diferentes ritos e prescrições, os quais esculpem uma faceta da cultura escolar e configuram a ação do professor e suas possibilidades de criação e autonomia (VOLOCHINOV/BAKHTIN, 2002).

A luta das forças monologizantes que se configura geralmente na prescrição - no currículo prescrito - é tencionada na luta pelo estabelecimento de uma concepção universalista de verdade, prefigurando em um currículo a ensinar. Essas correlações de forças e esses condicionantes sóciohistóricos formam o ambiente que estrutura a história ensinada. O cenário da ação e suas concepções e correlações de forças constituem o ensinado e sua plasticidade. Destacamos, ainda, que o professor goza de criatividade e autonomia relativa, questão fundamental para pensarmos e 
concebermos a plasticidade tanto da história ensinada e de sua produção de sentido quanto das práticas de letramento que se configuram em sala de aula.

A produção de sentido na história ensinada se constitui em ações múltiplas que dialogam com a tradição do ensino e com as contingências prescritivas de várias instâncias do processo educativo, dentre elas o currículo. Tais contingências dimensionam a ação do professor em sala de aula em uma expectativa macro e micro, pois dialogam com o mundo da vida que situa o ensinado em uma dimensão mais ampla que a prática - não se reduzindo apenas ao ato de fazer. O professor assume, assim, uma dimensão mais ativa e participativa, e seu fazer se constrói como uma ação complexa que extrapola as regras impostas e as normatizações vigentes. Nesse viés, o ensinado ganha o caráter de trabalho situado, complexo, híbrido e ambivalente, e a produção de sentido, concebida como uma ação do professor, requer desse sujeito múltiplos saberes, de diferentes ordens e campos discursivos.

Produzir sentido exige do professor um conhecimento do outro, mesmo que esse conhecimento seja uma concepção hipotética do aluno que está à sua frente, do entorno real ou imaginado que compõe a sua sala de aula, dos condicionantes curriculares, das estratégias avaliativas impostas pela hierarquia estabelecida e da tradição que constitui o ensino de história. Ao ensinar, o professor avalia seu tempo-espaço e, logo, conduz e constrói seus enunciados. Nesse processo, a avaliação, como aspecto arquitetônico do ato traz em si um conhecimento real, parcial, provisório ou hipotético de seu auditório social. Em suma, a produção de sentido na história ensinada estrutura-se pelas questões avaliativas que o ato arquitetônico enunciativo produz na constituição desse fazer.

O sentido não existe por si só; ele se faz em uma ação produtiva, historicamente situada. Como nosso foco é o ensinado, isto é, a ação do professor no processo de ensinoaprendizagem, dirigimos nosso olhar ao trabalho que esse ator constrói na produção de sentido.

O "sentido" resulta ser, portanto, o conjunto dos "significados agregados" que completam os "significados de partida". Os primeiros são seus antecedentes e, por isso, mesmo que possam ser presumidos ou permanecer inclusos, ocultos ou desconhecidos, têm sempre, mais ou menos, uma objetividade própria, uma materialidade histórica, uma autonomia sobre as intenções, sobre a vontade, sobre o projeto concreto e individual da comunicação [...] (PONZIO, 2008, p.99, grifo do autor). 
O sentido na história ensinada traz em sua tradição significados agregados que compõem o trabalho do professor e as práticas pedagógicas em sala de aula, mas também é desafiado pelos significados de partida, que refletem e refratam o cenário que compõe os temas no ensino. Ademais, tais significados são reinventados no fazer situado, produzindo outros sentidos para além da tradição. Mesmo na possibilidade de ruptura de significação, o significado, em primeira instância, requer um reconhecimento por parte do outro; logo, todo significado se constitui dessa dupla ação: agregados e partidos.

As práticas de letramento constituem e estruturam a produção de sentido na história ensinada, trazendo consigo significados agregados e significados de partida que se estruturam na tradição do ensinado e na inovação. Não obstante, esse cenário composicional desafia os professores no ato da história ensinada.

Dialogando com a teoria bakhtiniana, compreendemos história ensinada como um campo dialógico que é constrangido e contingenciado por múltiplas questões e, entre elas, o campo dialógico que é constrangido e contingenciado por múltiplas questões discursivas que permeiam o tempo-espaço escolar e a sociedade em seu espectro micro e macro social. Referimo-nos a gêneros que estruturam as práticas discursivas do campo e são formados e transformados no tempo-espaço.

Concebemos que a prática se constitui em um tempo-espaço de significação e, nele, os gêneros discursivos são trazidos pelos sujeitos em suas enunciações formadoras da história ensinada. Tais práticas discursivas não podem ser entendidas como um processo simétrico e harmonioso, visto que são produzidas em um tempo-espaço de disputa permeado pelas relações de poder situadas e históricas.

Dialogando com o referencial teórico bakhtiniano, podemos compreender as práticas discursivas que constituem a história ensinada como dialógicas. O “[...] dialogismo diz respeito ao permanente diálogo, nem sempre simétrico e harmonioso, existente entre diferentes discursos que configuram uma comunidade, uma cultura, uma sociedade" (BRAIT, 2005, p. 94).

A produção dos enunciados é intercambiável; assim, cada enunciado anuncia ao outro o processo dialógico que o compõe. A troca se estabelece em um tempo-espaço e o ato enunciativo se constitui com sujeitos situados.

[...] O enunciado é pleno de totalidade dialógica, e sem levá-la em conta é impossível entender até o fim o estilo de um enunciado. Porque a nossa própria ideia - seja filosófica, científica, artística - nasce e se forma no processo de interação e luta com os pensamentos dos outros, e isso não pode deixar de 
encontrar o seu reflexo também nas formas de expressão verbalizada do nosso pensamento (BAKHTIN, 2003, p. 298,grifo do autor).

O enunciado é proferido em uma relação avaliativa e, dessa maneira, cada indivíduo profere uma enunciação a partir de sua compreensão arquitetônica do tempo-espaço em que sua construção está se realizando. Em outras palavras, os atos enunciativos se constituem em diálogo com o mundo da vida que o permeia e o constitui. Já que essa questão é constitutiva do discurso, a construção enunciativa se estabelece na "totalidade dialógica" e o pensamento "individual" opera em processos dialógicos significados pelo tempo-espaço sócio-histórico. Vale lembrar que esse tempo-espaço se constitui de múltiplas "individualidades" socialmente constituídas, o que significa que o "meu" enunciado traz em si ecos e silêncios de vozes dos "outros" que constituem a subjetividade. Tais ecos e silêncios constituem o enunciado como único e situado, pois cada "palavra" adquire uma plasticidade mediada pelo universo discursivo concreto (VOLOCHINOV/BAKHTIN, 2002,p. 56).

A individualidade é concebida dentro de uma perspectiva situada, como as manifestações proferidas pelo indivíduo, marcadas pelo signo ideológico sócio-historicamente constituído. Assim, as formas de transmissão de um saber e a construção - individualizada - do conhecimento estão constituídas na esfera sócio-histórica situada. O indivíduo é dimensionado em uma relação social "eu para-o-outro, condição de interseção dessa identidade no plano relacional responsável/responsivo, que Ihe dá sentido" (SOBRAL, 2008, p. 22), e a identidade, nessa perspectiva, é intersubjetiva: eu sou eu, e sou e estou no outro que me constitui.

Tudo que me diz respeito, a começar pelo meu nome, chega do mundo exterior à minha consciência pela boca dos outros (da minha mãe, etc.), com a sua entonação, em sua totalidade valorativo-emocional. A princípio eu tomo consciência de mim através dos outros: deles eu recebo as palavras, as formas e a totalidade para a formação da primeira noção de mim mesmo. [...] Como o corpo se forma inicialmente no seio (corpo) materno, assim a consciência do homem desperta envolvida pela consciência do outro. Mais tarde começa a adequar a si mesmo as palavras e categorias neutras, isto eu e do outro (BAKHTIN, 2003, p. 373374).

Buscamos, nesse diálogo com Bakhtin, pensar a construção do conhecimento em uma relação intersubjetiva, historicamente situada no tempo-espaço que se constitui em uma constante plasticidade e incompletude. Nesse caminho, na perspectiva do tempo-espaço em construção e significação, no qual os enunciados se constituem enquanto materialidade significativa, o 
conhecimento é produzido por sujeitos socialmente constituídos, permeados pelos signos ideológicos de sua historicidade social (BAKHTIN, 2003).

A história ensinada como um campo de emprego da linguagem está impregnada dessas relações dialógicas. O professor, ao proferir o enunciado em sala de aula, dialoga com múltiplos campos discursivos, tecendo sentido sobre o passado ensinado. Sua explicação está impregnada de dialogismo oriundo de múltiplos campos discursivos (de seu cotidiano, das concepções de história e de educação, de seus valores pessoais etc).

O enunciado, sendo historicamente tecido e validado, é produzido pelo processo de valoração do sujeito com o outro e consigo mesmo. O processo valorativo se estabelece intersubjetivamente, do eu para com o outro e do outro para comigo. Assim, o conhecimento se constitui de validade e sentido em sua inserção em um contexto sócio-histórico relacional.

Desse modo, somente compreendemos as práticas de letramento em sua dimensão relacional, em seu contexto social e histórico, porque assim tecem os sentidos produzidos e atribuídos à sua materialidade.

\section{$3 \quad$ Aula típica ${ }^{3}$}

O evento em destaque se caracteriza como uma aula típica. Sua organização transcorre em momentos bem marcados, revelando um procedimento pedagógico típico desse professor e comum em várias aulas cotidianas.

O destaque dado a esse evento possibilita que analisemos práticas delineadoras da estética comum à sala de aula e à sua cotidianidade. Dessa maneira, compreendemos que as práticas de letramento são circunstanciadas pelo tempo-espaço sócio-histórico que as constitui de significado e relevância, agindo de forma estruturante na história ensinada. Descrever o cotidiano típico é fundamental na busca por analisar e compreender as práticas letradas que se corporificam no ensinado e o constituem de significação.

Dividimos a aula típica em 9 momentos distintos, são eles:

1) Chegada da turma e sua organização no espaço da sala de aula.

\footnotetext{
${ }^{3}$ O campo utilizado neste artigo foi produzido em uma escola estadual localizada na Baixada Fluminense/Rio de Janeiro, 60 ano de escolaridade. Aula ocorrida no dia 16 de Junho de 2009.
} 
2) Espera da turma pelo professor, chegada do professor e organização de seu material pessoal.

3) Transmissão de recados relevantes da semana ou de recados que a direção e/ou a coordenação pedagógica incumbiu o professor de transmitir.

4) Indicação de páginas e capítulo do livro que serão trabalhados na aula em questão;

5) Organização e distribuição da leitura entre os alunos da turma.

6) Explicação do conteúdo, usando o texto do livro como base.

7) Aplicação dos exercícios indicados no livro referentes ao capítulo lido e explicado;

8) Correção oral dos exercícios e escrita das respostas no quadro.

9) Realização da chamada da presença dos alunos.

Alguns elementos mudam de lugar na sequência dos acontecimentos no transcorrer das múltiplas aulas. O roteiro pedagógico ${ }^{4}$ está constantemente sendo adaptado ao imperativo do momento e às necessidades que constrangem o planejamento prévio estabelecido pelo professor, questão que aprofundamos na primeira cena em destaque do evento que compõe este artigo. Porém, os 9 momentos em destaque tradicionalmente formam a estética do evento aula em seus múltiplos desdobramentos.

O evento - Aula típica - recebeu essa nomeação por ser basicamente a dinâmica que se consolidou durante as aulas observadas em nosso campo de pesquisa. As práticas de letramento tradicionalmente, na sala de aula de Caio, recebiam um tratamento semelhante e constituíam uma dinâmica que compreendemos como o roteiro pedagógico básico de sua ação em sala de aula. Desse modo, elegemos o referido evento como relevante e sua análise fundamental para compreendermos as práticas que constituem o letramento e a produção de sentido na história ensinada.

A turma aguarda a chegada do professor em sala. Caio ${ }^{5}$, ao chegar, coloca seu material sobre a mesa e inicia a aula organizando a turma. O professor fala que havia planejado a aula para ser realizada no auditório, pois usaria o datashow, porém o rapaz responsável pela sala faltou e não lhe

\footnotetext{
${ }^{4}$ Usamos a expressão roteiro pedagógico no sentido de um itinerário constante e tradicional que o professor Caio realizava em suas aulas. Roteiro pedagógico, no uso que fazemos, nos remete a uma regulamentação organizacional das práticas de ensino que o professor realiza com sequenciamento em suas aulas.

${ }^{5}$ Nome fictício.
} 
era permitido instalar e usar sozinho os aparelhos. Dessa forma, como era obrigado a modificar seu planejamento, a aula se realizaria em sala de aula comum.

Vários alunos chegaram depois da entrada do professor. Nos minutos iniciais - cerca de 5 minutos -, a turma se prepara para a aula: os alunos ocupam as cadeiras e organizam os materiais sobre as suas mesas. Nesse processo de organização mútua - professor e alunos -, Caio utiliza o tempo para dar alguns recados e solicitar silêncio e atenção.

Neste artigo destacamos as cenas ${ }^{6}:$ 1) Aí eu marco; 2) Vamos abrir o livro; 3) Estou sendo prático.

Cena 1- Aí eu marco

Emissor Enunciado Falas

$\begin{array}{ll}\text { Caio } & \text { Ei... olha só... } \\ & \text { Já que o rapaz não veio e eu não posso mexer na aparelhagem. }\end{array}$

2 Então o que... que acontece, esse trabalho que seria hoje será feito na semana que vem... tá?

3 Aí eu marco para vocês...

Já marque aí no caderno de vocês, a avaliação que a gente vai fazer no dia 30.

430 não, dia 23.

Al $5 \quad$ Vai ser em dupla?

\footnotetext{
${ }^{6}$ As cenas são recortes do evento maior, a aula. 
Caio 6 Dia 23 não... desculpa, dia 30... dia 30 de junho. [uma aluna fala com ele - a filmadora não registra-ele dá o pincel e a aluna escreve a data da prova no quadro].

$\mathrm{Al}^{7} \quad 7 \quad$ Professor... professor, vai ser que dia?

Caio $\quad 8 \quad$ Dia 30.

9 [olha o relógio, controlando a hora que transcorre da aula]

O TESTE É DIA 30 DE JUNHO [fala mais alto chamando a atenção da turma que ainda está dispersa e conversando].

A aula, como vários rituais, possui procedimentos padrões e normas institucionais definidas sócio-historicamente. Dessa forma, os procedimentos pedagógicos estão sujeitos a regras e condicionantes sociais definidos pela estrutura hierárquica em que está inserido o ensinado.

Como já afirmado, acreditamos e defendemos que o professor é um ator ativo e protagonista do ensinado, porém não podemos negar que esse processo está imerso no caldo cultural, social e histórico que constitui a escola como instituição e espaço social, isto é, o ensinado é tanto impactado pelas correlações de poder em uma perspectiva relacional micro e macro, quanto as impacta.

Nesse evento, o professor organiza previamente a aula e as estratégias utilizadas para construir o sentido do passado que busca transmitir e fixar para os alunos. Tal planejamento é fortemente impactado pelas dinâmicas sociais que se desenrolam no espaço escolar. Como podemos observar [E: 1 e 2 $]^{8}$, o professor Caio pretendia utilizar a sala de multimídia e o datashow, pois o seu planejamento inicial possuía o objetivo de apresentar a aula e desenvolver um trabalho com finalidade avaliativa - avaliação de recuperação paralela ${ }^{9}$ - obedecendo, assim, a um planejamento institucional prévio, que estabelece etapas e práticas avaliativas.

\footnotetext{
${ }^{7}$ Al: Aluno: Indeterminado.

${ }^{8}$ E: enunciado. 1 e 2: linhas correspondentes da transcrição.

${ }^{9}$ Avalição que visa recuperar alunos que apresentaram rendimento inferior a nota 5 no bimestre.
} 
O planejamento foi frustrado e o professor reorganizou sua aula. Essa estratégia, para atender o acontecimento inesperado, que impactou seu planejamento prévio, exigiu do professor um conhecimento pedagógico de outra ordem, que não o historiográfico. Caio, ao estabelecer um novo roteiro pedagógico, buscou o saber curricular, relacionado aos conteúdos e à dinâmica maior que constitui o ensinado e o seu lugar na história ensinada no processo pedagógico educacional.

[...] Conhecimento curricular (curricular knowledge) - Conhecimento sobre o currículo, que "é o conjunto de programas elaborados para o ensino de assuntos específicos em um nível dado, a verdade de matérias instrucionais disponíveis relacionadas a esse programa", e sobre o conjunto de características que servem como indicações ou contra-indicações para o uso do currículo [...] (MONTEIRO, 2007, p. 191, grifo do autor).

O processo de ensino está submetido a múltiplos procedimentos e, entre eles, estão os avaliativos [E: 3] - não é por acaso que Caio destaca a marcação da prova. Diante de um fato consumado - a impossibilidade do uso do datashow -, o professor utiliza a aula para ensinar e fixar os conteúdos que comporão a prova que ocorrerá em duas semanas subsequentes.

Diante do fato consumado - a impossibilidade de usar a sala de multimídia -, o professor coloca o livro como o principal aporte pedagógico, uma vez que é o que the socorre diante do desmonte de seu planejamento prévio. São as contingências que agem com forte impacto sobre o ensinado e tornam a ação do professor um fazer que se caracteriza por sua autonomia parcial e flexível e por ineditismos circunstanciados pelo imperativo do situado.

Vale frisar a autonomia, pois, mesmo submerso em condições que lhe tolhem e modificam o planejamento primeiro, o professor possuía outras alternativas na condução de sua aula, podendo escolher ir por outra direção, mas ele faz uma opção lógica e prática, como se observa em outra cena. O conhecimento dos condicionantes e do processo em que o ensinado está imerso conduz, de certa forma, a escolha estética e as práticas de letramento que se desdobram no referido evento. Caio mira o simulado, seu conteúdo e formato, buscando preparar cotidianamente sua turma para a feitura da tarefa avaliativa.

O simulado $^{10}$ talha fundamentalmente a face e as práticas que compõem o campo de pesquisa investigado. $O$ instrumento avaliativo local possui uma dimensão e uma compreensão que vai além de sua aplicação por parte do professor e da comunidade escolar. O simulado é compreendido como um elemento de organização e propulsor de elevação da qualidade do ensino e

${ }^{10}$ Avaliação bimestral instituída pela escola, de formato objetivo que impacta em $50 \%$ a nota final do aluno. 
da visão que a comunidade possui em relação à escola. Nesse sentido, em diferentes momentos, observamos o esforço coletivo da comunidade escolar destinada à missão de organizar e promover junto aos alunos a participação e a cooperação para a realização do simulado.

Cena 2 - Vamos abrir o livro

Emissor Enunciado Falas

Caio $\quad 1$ Então vamos lá, vamos abrir o livro na página 90, por favor...

2 PÁGINA 90, tô vendo livro fechado... e livro ainda na mochila... Vamos lá...

$3 \quad$ Antes de complementar com o caderno... eu queria ver com você um negócio no livro.

$4 \quad$ O livro na página 90 o título dele é... A religião e a escrita.

$5 \quad$ A religião de certo modo a gente já falou sobre ela... né?

6 A gente já viu algumas características da religião egípcia... que taí no caderno...

7 Ela é politeísta... né, isso? Que acreditavam em vários deuses.

E outra característica que vocês acharam curioso, é aquela palavra gigante que eu coloquei no quadro...

Que os deuses tinham que característica?

Al $\quad 8 \quad$ Cabeça de animal e corpo de pessoa. 
Al Antropozooformófica [vários alunos falam ao mesmo tempo a palavra com uma nítida dificuldade, silabando].

Caio $10 \quad$ Antropozoomórfica... forma de homem e de animal...

Sarah $\quad 11$ Antropozoomórfica...

Caio 12 Isso, Sarah perfeito...

13 E aí... Falta um aspectozinho simples... /psiu... psiu/

14 Falta um aspectozinho rápido sobre a religião, sobre a religião, sobre a sociedade, né, que eu não vou colocar no caderno... que eu quero que a gente leia no livro.

Na 90, a gente viu /psiu/

Pera aí, galera... sem tumulto...

É a gente vai então... já que na página 90 a gente viu os aspectos da religião... inclusive mumificação, contei como funciona, etc e tal... A gente vai para a página 91 que tá falando sobre a escrita... *

A gente vai ver que a escrita da... do Egito Antigo também tem a ver com religião, tá...

15 A gente vai começar a ler...

Por favor... por amor de Jesus agora você leia sem berrar. [vários aluno riem do comentário do professor]

Você tá gritando aí 500 anos que quer ler, vai lá...

[A turma ri da fala do professor].

16 A escrita no Egito

Educação: Teoria e Prática/ Rio Claro/ Vol. 23, n.44/ p. 05-17/ Set-Dez. 2013. 
A primeira forma de escrita no Egito...

17 Eu falei que a gente ia ler a página 91 que a 90 eu já expliquei.

Eu só apresentei a 90 para vocês...

$A l$

Não, ela pediu primeiro... Você lê daqui a pouquinho... lago lê daqui a pouquinho* Vinícius... Todo o mundo vai ler.

Caio

Começa... silêncio, gente /psiu/

$A l$

18 A escrita no Egito

A primeira forma de escrita no Egito foi o hieee...

Caio 19 HIERÓGLIFO

$A l$

20

Hieróglifo. Os sinais dessa escrita representam ideias e sons. Por exemplo, o desenho de uma coruja representava o objeto coruja e $\mathrm{som} / \mathrm{m} /$. Era uma escrita muito complexa e demorada, gravada em madeira, pedra ou metal. Devido a essa dificuldade, apenas os escribas dos templos tinham o hábito de usá-la.

Caio 21 [interrompe a aluna e inicia a explicação] Então olha só... é... o primeiro tipo de escrita que a gente tá vendo... e talvez a mais importante é a escrita hieroglífica... que são os hieróglifos que ela acabou de ler... são símbolos, são sinais, que correspondem tanto a objetos, quanto a gente poderia transferir\#...

22 Tem um exemplo que tá bem pequenininho na página 91, não dá para enxergar direito eles não... 
Mas toda essa... essa imagem, é... se vocês olharem os detalhes, vocês vão ver os hieróglifos aí...

Se a gente pudesse estar lá, eu mostraria com mais clareza os hieróglifos.

A cena - Vamos abrir o livro - deve ser compreendida no contexto comunicativo em que se constitui. A escolha da leitura do livro está imersa no contexto em que o ato está inserido. Como já analisamos na cena anterior, esse procedimento didático não era o planejado pelo professor, mas, diante dos acontecimentos que se desdobraram no encaminhamento da aula, o professor usou a leitura do livro como o procedimento condutor de sua aula.

Em diversas pesquisas, os livros didáticos aparecem com "a função de portadores dos conteúdos explícitos e de organizadores das aulas de História nos níveis fundamental e médio da educação escolar brasileira" (GATTI JUNIOR, 2004, p. 16). Na sala de aula que investigamos, esse papel se torna claro e constante, pois o livro também assume o papel de elemento fundamental nas práticas de letramento. Sua estética composicional dá o tom das aulas, seu arcabouço fraseológico e vocabular delineia as explicações e os exercícios aplicados. O livro traz em si uma organização vocabular escolar histórica utilizada pelo professor na organização de sua explicação, como um elemento básico que ele vai proferindo, alterando, desprezando e transformando diante do imperativo pedagógico escolar que se forja no momento da aula.

Na explicação do conteúdo, o professor destaca o significado das palavras politeísta e antropozoomórfica [E: 7 a 11]. Mais que simples palavras que ocupam o vocabulário do ensino de história, trata-se de conceitos que pertencem ao campo discursivo da história acadêmica e escolar, com significados tecidos para dar sentido ao passado, sentido, este, que extrapola o campo discursivo e modela, de certa forma, o pensamento das pessoas sobre o tempo-espaço que compõe a civilização egípcia e seu período histórico.

Ao ensinar as palavras, o professor introduz os alunos em uma prática de letramento da história como campo discursivo submetido às regras e aos constrangimentos dessas mesmas práticas. Sendo assim, o professor, ao explicar politeísmo e antropozoomorfia, está letrando os alunos e aproximando-os desse campo discursivo e de seu vocabulário e arcabouço conceitual.

Nessa cena, o enunciado [15] chama nossa atenção pela ironia e pela brincadeira que o caracteriza. A aluna, que, antes de o professor permitir a leitura, pede insistentemente para realizar a tarefa, é um tanto quanto levada e agitada. O professor, em outra aula não apresentada em nosso 
artigo, avisa que ela leria se apresentasse um comportamento adequado ${ }^{11}$. Na cena, o professor une a sua explicação - relativa à religião egípcia - ao pedido que faz à aluna, trazendo a questão para a referência religiosa da maioria da população atendida na escola ${ }^{12}$. Ao falar - Por favor... por amor de Jesus, agora você leia sem berrar -, o professor busca, também, exercer um controle sobre a turma. $\mathrm{Na}$ fala, ele não só dialoga com a aluna, como indica à turma o tom de voz que ele considera legítimo para ser usado em sala, em um tom de brincadeira que leva a turma a rir de sua fala e aceitar a ordem implícita que está sendo proferida.

A prática de leitura ganha mais que um significado letrado; ganha um sentido pedagógico e organizador da aula. Na cena a seguir, a partir da qual analisamos as práticas de letramento situadas em sua função pedagógica organizadora, apenas destacamos a questão da leitura.

A aluna lê o trecho indicado e, logo no início, sente dificuldade em ler uma palavra - $A$ primeira forma de escrita no Egito foi o hieee... -, o professor completa a palavra em voz alta chamando a atenção da turma. A prática que destacamos ocorre repetidas vezes em diferentes aulas. O professor acompanha a leitura e a corrige quando esta não corresponde à forma correta. Em outros eventos, Caio, ao perceber que os alunos supostamente não saberão falar a palavra, sobrepõe sua voz à do leitor e lê a palavra de forma correta, para que o aluno a repita, seguindo o exemplo do professor. Essa prática pedagógica de leitura e correção possui um caráter formador e corretivo, pois visa a corrigir os erros cometidos e ensinar os alunos sobre o padrão de pronúncia de determinadas palavras presentes no vocabulário escolar histórico.

A aluna retorna à leitura [E: 19] repetindo a palavra de forma correta e, na sequência, o professor interrompe a leitura para explicar o conteúdo [E: 22]. Esse procedimento também é cotidiano nas aulas observadas. A explicação consiste em um processo de parafrasear o livro e juntar elementos próximos ao cotidiano dos alunos, buscando fazer com que compreendam e se aproximem do conteúdo apresentado. A incorporação de expressões mais coloquiais e gírias, por exemplo, busca fazer que o texto oral ganhe uma estética mais próxima à fala cotidiana.

A explicação mesclava um tipo de oralidade letrada, isto é, a fala ficava muito próxima ao texto escrito e à oralidade cotidiana, a qual serve como elemento de aproximação do auditório social. Em sua explicação, o professor incorporava gírias e palavras usadas pelos alunos em suas conversas espontâneas, fazendo com que sua fala possuísse certa leveza e se aproximasse da oralidade cotidiana dos alunos.

\footnotetext{
${ }^{11}$ Anotação do caderno de campo 31/03/2009.

${ }^{12} \mathrm{O}$ último censo indica que a maioria da população na Baixada Fluminense professa o credo cristão.
} 
No enunciado a seguir, o professor destaca uma imagem do livro e retorna à questão de não estar na sala de multimídia, "Se a gente pudesse estar lá, eu mostraria com mais clareza os hieróglifos". Como vemos a seguir, esse conteúdo comporá o simulado e, dessa maneira, a aprendizagem e a fixação dele é fundamental no processo avaliativo que se seguirá a essa aula.

A imagem que o professor aponta como contendo um exemplo de hieróglifo poderia ajudar a compreensão dos alunos se fosse apresentada no livro em um tamanho maior. No livro ${ }^{13}$, ela compõe de forma ilustrativa o texto, não sendo elemento constitutivo da explicação do conteúdo, pois cumpre a função ilustrativa e não viabiliza a sua utilização como texto imagético (figura 1).

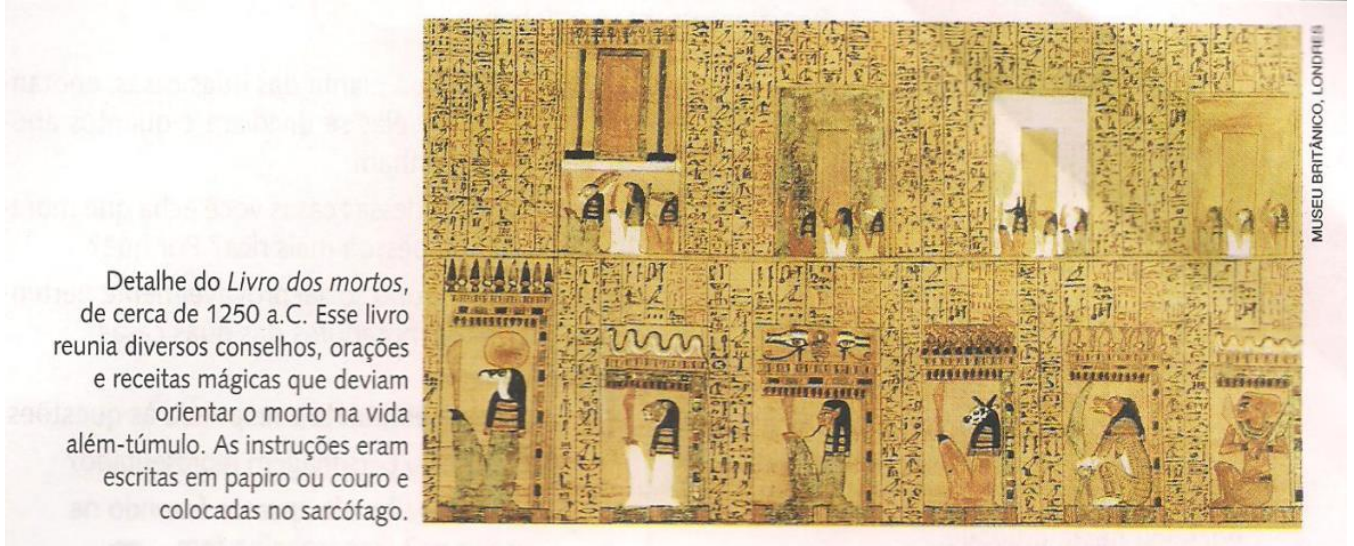

Figura 1 - Ilustração do livro utilizado pelo professor Caio

Como podemos observar, em suma, a imagem não destaca elementos que compõem a escrita egípcia e, em razão disso, está no livro com uma função estética e ilustrativa. O tamanho dificulta a possibilidade de o professor explorar os caracteres que compõem a escrita e aprofundar a questão com os alunos. A imagem, como parte do livro dos mortos, ajudaria a construção argumentativa do professor, mas seu formato no corpo do texto impede essa possibilidade, pois o livro didático, muitas vezes, dificulta seu uso e a construção do sentido que o professor busca apresentar aos alunos.

O trabalho realizado na referida cena possui um caráter marcado pela fragmentação de informações históricas. Diante desse fato, nos questionamos sobre que sentido o aluno construirá diante dessa estética enunciativa.

\footnotetext{
${ }^{13}$ O livro utilizado pela turma foi recebido em 2008, e pertence à Coleção - Projeto Araribá, organizada pela Editora Moderna.
} 
Cena 3 - Estou sendo prático

Emissor Enunciado Falas

Caio 1 Com relação à escrita do Egito Antigo, comentando com um pouquinho mais de detalhe... inclusive lendo o livro por causa do simulado de vocês

2 Estou sendo prático [sinaliza com a mão indicando afunilamento ou foco].

3 Então, o que isso significa... significa que para questões de estudo vocês firmem bem esta página... tá?!...

$4 \quad$ O simulado são questões de múltipla escolha, fiquem atentos à múltipla escolha, e atentos a esse tipo de estudo... tá?!...

$5 \quad$ * Vou pensar num tipo de teste assim para a gente... aprender a fazer.

A racionalidade que conduz essa cena é a principal questão que permeia toda a aula. Como a sala multimídia não estava disponível, o professor, para construir o perfil da aula e das práticas de letramento que a comporiam, saca do seu conhecimento sobre o currículo, sobre as questões que permeiam esse processo e, em especial, sobre a avaliação.

Sua decisão ou sua escolha pedagógica busca garantir que a aula transcorra, mesmo não seguindo o planejamento prévio - Estou sendo prático. O professor realiza um julgamento que se desdobra nas práticas de letramento que constituem o evento - a aula típica.

O julgamento foi realizado pelo professor diante das relações sócio-históricas que constituem a sala de aula e são impactadas por aspectos relacionais micro e macro do tempo-espaço que a constituem e se desdobram nos encaminhamentos pedagógicos da aula.

A página escolhida para a aula não foi ao acaso ou seguiu apenas o roteiro preestabelecido do livro. Caio destaca a página, e a leitura é realizada mediante questões maiores que o impacto da não disponibilidade do material agendado previamente. A escolha e a transmissão da matéria em 
questão - escrita no Antigo Egito - são fruto de uma racionalidade que avalia o seu tempo-espaço, como o professor mesmo afirma - Estou sendo prático. Uma perspectiva de prática, que extrapola o ato em si, está sendo significada pelo situado e pelo impulso socioeducativo que a fixação do conteúdo pode possibilitar na feitura da prova por parte dos alunos.

Nessa perspectiva, retornamos a uma questão que afirmamos repetidamente compreendemos o ensinado como um fazer que possui uma autonomia relativa. O professor, mesmo circunstanciado e constrangido pela falta do datashow, toma decisões e realiza escolhas, dialogando com o mundo da vida que constitui o ensinado e com a sua concepção de ensino.

Outro professor, com outra concepção de compromisso e de currículo escolar, circunstanciado por outro tempo-espaço sócio-histórico, poderia optar por aplicar, hipoteticamente, uma atividade livre, rompendo com o currículo proposto e com suas estratégias de manutenção. A escolha poderia ser legítima, dependendo do que ele elaborasse para a aula. Possuiria um valor pedagógico? Talvez. Teria um efeito prático? Dependeria de que efeito estamos considerando. Uma aula que buscasse as imagens do livro e sinalizasse que a figura feminina tem raríssima participação na historiografia escolar apresentada poderia, em uma perspectiva de militância, ser válida.

Essa questão comporia o simulado em nossa realidade de pesquisa? Não. Mas poderia ter um efeito social importante para esses alunos? Denotaria um compromisso social com o ensinado, mesmo que esse compromisso não fosse o desejado pela escola e pelo sistema de educação em uma perspectiva macro. É possível que ocorresse, mas não é a realidade que encontramos em nosso campo. Por que, então, apresentamos essa hipótese de roteiro pedagógico? Para salientar que o ensinado está constituído em suas relações sociais e históricas, circunstanciadas pelo tempo-espaço e pelas intersubjetividades que constituem sua materialidade discursiva.

Caio segue uma racionalidade que tem como principais argumentos de validez o simulado e a preparação dos alunos para o mesmo. A nosso ver, a racionalidade possui validez, sim, pois dialoga com o complexo relacional que constitui o ensinado. Sendo assim, ela é justa e inserida no contexto e os procedimentos pedagógicos utilizados, também. Diante do imprevisto, usa-se o que se possui - o livro e a leitura do mesmo - e se direciona para o caminho pelo qual se acredita realizar o melhor trabalho possível.

Uma questão pode surgir ao leitor deste artigo: então, a referida aula não é uma aula típica? Por que tal aula é definida como típica? Definimos como típica, porque esse procedimento de pautar a aula no livro didático é um padrão recorrente desse professor e é o livro didático, de fato, um dos 
poucos materiais sempre disponíveis e acessíveis ao professor e aos alunos no cotidiano da sala de aula.

A escola possui apenas uma sala de multimídia e as cópias - xérox de textos - destinam-se exclusivamente às provas e testes. A televisão, o datashow e o rádio estão todos alocados na sala de multimídia, com um funcionário responsável pela instalação dos mesmos. Isso significa que o acesso a tais materiais é limitado, já que só podem ser usados mediante agendamento e disponibilidade. Dessa forma, o uso do livro torna-se o principal suporte pedagógico nas aulas.

A prática de letramento que circunda o livro didático está envolta por questões de múltiplas ordens e relações de poder. O livro é comprado a cada três anos, a partir da escolha de três coleções, em ordem de preferência, pela equipe de professores. Entretanto, a coleção escolhida em primeiro lugar pode chegar ou não. Em nosso campo de pesquisa, por exemplo, o livro usado não foi a primeira escolha. Vale incluir que é o governo federal que compra os livros e encaminha para as escolas. Outra questão fundamental é a oferta dos livros aos alunos durante esse período, visto que não são repostos na mesma medida em que as necessidades aparecem. Esse fato gera turmas inteiras sem livros, produzindo um impacto ainda maior na organização das aulas e nas práticas pedagógicas que constituem a história ensinada.

\section{$4 \quad$ Para concluir}

Para compreender a história ensinada, é fundamental, no viés teórico que usamos, lançar um olhar sobre a produção de sentido, pois esse movimento dimensiona o ensinado em uma perspectiva sócio-histórica e o percebe em seu tempo-espaço situado.

As práticas de letramento que se constituem na história ensinada são significadas em seu contexto sócio-histórico; logo, falar, ler e escrever não podem ser analisados de forma isolada ou puramente quantitativa. Para compreender tais práticas, é necessário compreender os sentidos produzidos de forma contextualizada, pois as enunciações são impregnadas de coisas presumidas e não ditas, elementos estes compreendidos na vivência de produção do ato discursivo.

As práticas de letramento na história ensinada são constituídas nesse todo relacional. Os atos de ler o livro, copiar do quadro, escrever no caderno e responder a prova são práticas contextualizadas na vida escolar. Seus sentidos e suas significações enunciativas são de natureza social; dessa forma, é no contexto social que os sentidos são produzidos e sua validade é aceita. 
As práticas de letramento possuem uma singularidade significativa do tempo-espaço que as constitui de sentido e validade - o aqui e o agora que fomentam a capacidade responsiva do enunciado -, porém não podemos esquecer que esses elementos do ato em si estão posicionados historicamente. O reconhecimento do outro é fundamental para que a resposta ocorra, pois o enunciado conclama o outro para uma resposta, mesmo que esta seja o silêncio.

As práticas de letramento, sejam na história ensinada sejam no mundo, são circunstanciadas e validadas pelo contexto de vida, não podendo ser analisadas, categorizadas ou compreendidas fora da produção de sentido que as constitui e estrutura seus atos. Em virtude disso, tais práticas são sempre sociais e marcadas pelo tempo-espaço que as compõe enquanto materialidade e validade. No caso, na história ensinada, elas são constituídas pela perspectiva escolar, histórica, social e filosófica que recobre seus atos e, assim, os sentidos produzidos em práticas de letramento.

\section{Referências}

BAKHTIN, M. Estética da criação verbal. 4. ed. São Paulo: Martins Fontes, 2003.

BAKHTIN, M. Toward a Philosophy of the Act. Translation and notes by Vadim Liapunov. Edited by Vadim Liapunov and Michael Holquist. Austin: Universtity of Texas Press, 1993.

BRAIT, B. (Org.). Bakhtin, dialogismo e construção de sentido. 2. ed. Campinas: Editora da Unicamp, 2005. Inserir p.1 - 365.

FARACO, C. A. Linguagem e dialogo: as ideias do Círculo de Bakhtin. São Paulo: Parábola, 2009.

GATTI JÚNIOR, D. A escrita da história: livro didático e ensino no Brasil. Bauru: Edusc, 2004.

MONTEIRO, A. M. da C. Professores de História: entre saberes e práticas. Rio de Janeiro: Mauad X, 2007.

PONZIO, A. A revolução bakhtiniana. São Paulo: Contexto, 2008. 
SOBRAL, A. Ato/atividade e evento. In. BRAIT, B. (Org). Bakhtin: conceitos-chaves. 4. ed. São Paulo: Contexto, 2008. p.11 - 36.

VOLOCHINOV/BAKHTIN, V. N. Marxismo e filosofia da linguagem. 9. ed. São Paulo: Hucitec/Annablume, 2002.

Enviado em Agosto/2012

Aprovado em Novembro/2013 